

$1916 \cdot 2021$

\title{
ECOSYSTEMS
}

\section{Diversity of non-marine gastropods of the Fiocruz Atlantic Forest Biological Station and adjacents urban areas, Rio de Janeiro, RJ, Brasil}

\author{
FLAVIA C.S. RANGEL, SUZETE R. GOMES, THAMIRES CANUTO, \\ PAULO S. RODRIGUES \& SILVANA C. THIENGO
}

\begin{abstract}
Our main objective was to perform a preliminary survey of the non-marine gastropods at the Estação Biológica Fiocruz Mata Atlântica (EFMA) and its adjacent urban areas, also considering samples from other localities of the Parque Estadual da Pedra Branca received as donation, in Rio de Janeiro, RJ, Brazil. Infection by larval helminths of medical and veterinary importance was also investigated in 348 specimens of five freshwater species and two specimens of the terrestrial species Achatina fulica. In all, 584 samples of molluscs from 34 collection sites were obtained. They represented 31 species classified in 16 families. Fifteen species were exclusive to the EFMA area. In the urban area mainly exotic and/or synanthropic species were found. Some of them were found in the forest border as well. The freshwater Biomphalaria tenagophila, an intermediate host of the trematode that causes schistosomiasis mansoni, was found parasitized by Xiphidiocercarie cercariae and the Afro-asiatic Melanoides tuberculata by Pleurolophocercus cercaria. The finding of endemic and exotic species, including transmitters of parasites, demonstrate the importance of fast surveys such as the present study. However, considering the great diversity of endemic molluscs found in a relatively small part of the EFMA, we highlight the necessity of further additional studies.
\end{abstract}

Key words: Atlantic Forest, Gastropoda, biodiversity, associated helminths.

\section{INTRODUCTION}

Introduction and establishment of exotic and invasive species are facilitated in environments altered by human action. This fact has caused serious problems that affect native species conservation, as well as human health. Faunal inventories/surveys play an important role in assessing and managing these invasive species as well as the management of wildlife resources. (MMA 2006).

Gastropod species are considered good bioindicators of environmental health due to their relative lower dispersion capacity, associated to stable microclimate dependence, relatively strict habitat preferences and high sensitivity to environmental conditions (Kappes et al. 2009, Altaf et al. 2017, Nicolai \& Ansart 2017). On the other hand, freshwater and terrestrial gastropods can act as intermediate hosts of helminths that cause diseases to human and animals (MS 2008, Ohlweiler et al. 2010). Other species can be invasive, becoming important crop and urban pests that can compete with native species for resources (Barker 2002, Fernandez et al. 2003, Dreves et al. 2017).

The Parque Estadual da Pedra Branca (PEPB) is recognized as one of the largest urban forests in the world and the largest in Brazil (INEA 2013). It has an important role in the water and climate 
balance of Rio de Janeiro, occupying about 10\% of its territory. It has an area of $125 \mathrm{~km}^{2}$ and it protects more than $50 \%$ of what remains of the Atlantic Forest in the city (INEA 2013). The Campus Fiocruz Mata Atlântica (CFMA) is located in the neighborhood of Jacarepaguá, Rio de Janeiro, RJ and belongs to the Fundação Oswaldo Cruz. It is bordered by PEPB, between an Atlantic Forest area and a disordered urban area, with high interaction between wild and domestic animals. The Campus includes a secondary Atlantic Forest vegetation (Souza et al. 2015), representing the Estação Biológica Fiocruz Mata Atlântica (EFMA), which overlapping its area with the PEPB.

Studies on the land molluscs of the Rio de Janeiro state are scarce and none has dealt with the area of PEPB. The results of Santos et al. (2003) in the PEPB were restricted to freshwater species. Thus, the objective of present study was to perform a preliminary survey of the nonmarine gastropods in the EFMA, as well as in its adjacent urban areas, also considering samples from other localities of the PEPB received as donation. Parasitological analyses of some species (all freshwater and one terrestrial) were also performed, aiming to investigate possible infection by larval helminths of medical importance, such as those that cause schistosomiasis and angiostrongyliasis (abdominal and cerebral).

\section{MATERIALS AND METHODS}

Mollusc samples were obtained from 34 sites distributed in two different areas within CFMA: a semi-preserved forest at the EFMA and an urban and adjacent area to EFMA (Figures 1, 10a, Collection License number 51246-2- Instituto Estadual do Meio Ambiente - INEA). Fifteen sites were in the forest area near the main EFMA trail. The other nineteen sites were in urbanized areas in the following communities: Fincão, 1.

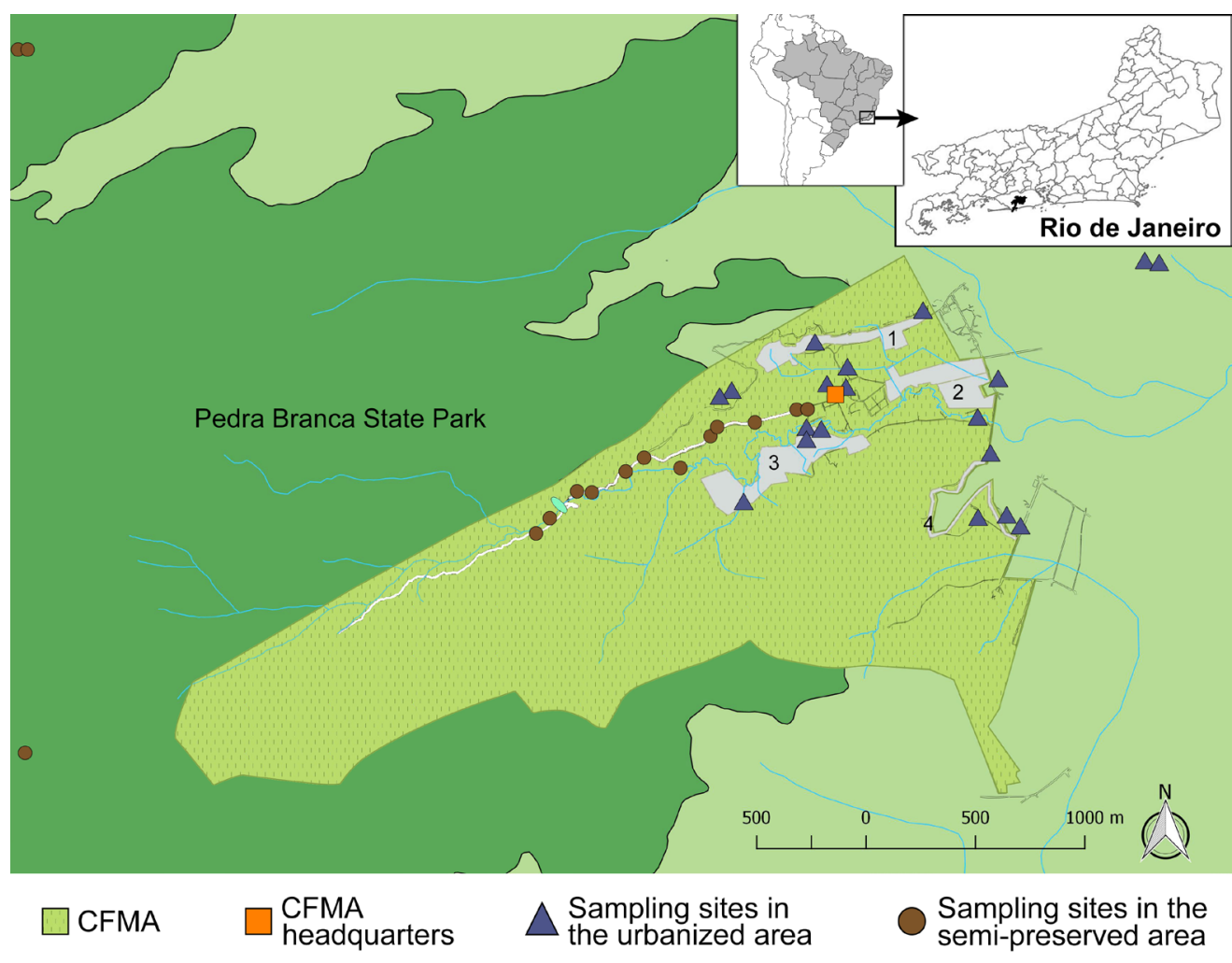

Figure 1. Location of the Pedra Branca State Park, Rio de Janeiro, Brazil. Brown circles represent the sampling sites in semi-preserved Forest. Blue triangles represent the sampling sites in adjacent urban areas. Sampled communities 1. Caminho da cachoeira; 2. Sampaio Correa and Viana do Castelo; 3. Fincão; 4. Faixa Azul and Nossa Senhora dos Remédios. 
Caminho da cachoeira; 2. Sampaio Correa and Viana do Castelo; 3. Fincão; 4. Faixa Azul and Nossa Senhora dos Remédios and the CFMA building area. Samples from the locality Pau da Fome, which is not part of EFMA but belongs to the PEPB, were received as a donation, and were also analyzed. The geographic coordinates of each collection site were used to construct a map using the QGIS (2.0) georeferencing program (QGIS Development Team 2017). The collection sites were chosen to compare the species in both areas, aiming to identify the native fauna and to investigate the exotic and/ or intermediate hosts species of helminths of importance. Sampling was carried out from November 2017 to March 2018, representing the rainy season (Siciliano et al. 2018). Shells and live animals were sampled using active search method with all specimens being handcollected in the field and photographed at the laboratory. In the forest the search was made in lower trunks, leaves and branches of trees, shrubs, and leaf litter. The collectors ranged from four to six per sampled site and dedicated 20 minutes per site. All the sampled specimens are deposited at the Coleção de Moluscos do Instituto Oswaldo Cruz (CMIOC 11.106 - 11.206, 11649-11650) (Table I).

Freshwater specimens were fixed according to MS (2008), except for Melanoides tuberculata (Müller, 1774) and Pomacea sordida (Swainson, 1823) that followed Fukuda et al. (2008). All live freshwater specimens were exposed to four hours of light and four hours of darkness to induce possible cercarial shedding according to Thiengo et al. (2012). Cercarian types were identified based on Pinto \& Melo (2013). Procedures for the morphological identification of freshwater snails followed Simone (2006), MS (2008), Ohlweiler et al. (2010) and Thiengo et al. (2011).
Terrestrial specimens were fixed according to Thomé (1975) and classification of the families followed Bouchet et al. (2017). Several annotated type catalogues were used to species identification (Simone 2006, Breure \& Ablett 2011, 2012, 2014, 2015, Breure \& Araújo 2016).

Two specimens of the African giant snail Achatina (Lissachatina) fulica Bowdich, 1822 were digested with chloridric acid $0.7 \%$ solution (Graeff-Teixeira \& Morera 1995), to recover possible nematode larvae of medical and veterinary interest.

\section{RESULTS}

In total, 584 samples of molluscs were obtained (shells and living specimens). A total of 31 species were found, of which 26 were terrestrial (12 families) and five were freshwater species (four families) (Table I, Figure 9a-e). Among the terrestrial families, Subulinidae, Bulimulidae and Simpulopsidae were those with the highest number of species, whereas for freshwater was Physidae.

Most species were collected alive and those represented only by shells were: Anthinus multicolor (Rang 1831), Lopesianus crenulatus Weyrauch, 1958, Tamayoa banghaasi (Thiele 1927), Beckianum beckianum (Pfeiffer 1846), Allopeas micrum (d'Orbigny 1835) and Allopeas gracile (Hutton 1834).

\section{Atlantic Forest area}

In the semi-preserved Atlantic Forest (EFMA) among the 20 collected species only one was freshwater, the Afro-asiatic Melanoides tuberculata (Figure 9d) (Table I). The terrestrial taxa belong to the following families: Bulimulidae, Helicinidae, Megaspiridae, Neocyclotidae, Simpulopsidae, Streptaxidae, Scolodontidae, Strophocheilidae, Subulinidae 
Table I. List of continental mollusc species found in the Pedra Branca State Park, Rio de Janeiro, RJ and adjacent urban areas, including their Family, area where they were found (Forest or Urban area), number of the lots in the Coleção de Moluscos do Instituto Oswaldo Cruz, number of collected specimens $\left(\mathrm{N}^{\circ}\right)$ and if is considered exotic or native in Brazil.

\begin{tabular}{|c|c|c|c|c|c|}
\hline Family & Terrestrial species & Area & Lots- CMIOC & $\mathbf{N}^{\circ}$ & $\begin{array}{l}\text { Exotic/ } \\
\text { Native }\end{array}$ \\
\hline Achatinidae & Achatina fulica & Urban & $11190,11199,11205$ & 5 & Exotic \\
\hline Helicinidae & Helicina angulata & Forest & $11106,11110,11168,11175$ & 10 & Native \\
\hline Neocyclotidae & Neocyclotus prominulus & Forest & $11115,11155,11160,11172,11179,11184$ & 31 & Native \\
\hline \multirow[t]{2}{*}{ Veronicellidae } & Latipes sp. & Urban & 11137 & 2 & Native \\
\hline & Phyllocaulis boraceiensis & Forest & 11203 & 1 & Native \\
\hline Agriolimacidae & Deroceras laeve & Urban & $11124,11144,11200$ & 3 & Exotic \\
\hline \multirow[t]{3}{*}{ Bulimulidae } & Bulimulus tenuissimus & Forest/Urban & $11112,11114,11131,11143$ & $3 / 24$ & Native \\
\hline & Drymaeus papyraceus & Urban & 111148,10005 & 2 & Native \\
\hline & Lopesianus crenulatus & Forest & 11159 & 1 & Native \\
\hline \multirow[t]{3}{*}{ Simpulopsidae } & Leiostracus perlucidus & Forest & $\begin{array}{c}\text { 11111, 11117, } 11121,11122,11154,11174 \\
\text { 11180, } 11185\end{array}$ & 13 & Native \\
\hline & Rhinus ciliatus & Forest & $11118,11163,11166,11167,11181$ & 5 & Native \\
\hline & Simpulopsis sulculosa & Forest & $11173,11176,11177$ & 4 & Native \\
\hline \multirow[t]{2}{*}{ Megaspiridae } & Thaumastus taunaisii & Forest & 11135 & 5 & Native \\
\hline & Megaspira elatior & Forest & 11157,11161 & 8 & Native \\
\hline \multirow[t]{2}{*}{ Streptaxidae } & Streptaxis crossei & Forest & 11156,11182 & 3 & Native \\
\hline & Streptaxis sp. & Forest & 11178 & 2 & Native \\
\hline \multirow[t]{2}{*}{ Scolodontidae } & Tamayoa banghaasi & Forest/Urban & $1108,11131,11170$ & $4 / 1$ & Native \\
\hline & Happia vitrina & Forest & 11162,11204 & 4 & Native \\
\hline \multirow[t]{3}{*}{ Strophocheilidae } & Anthinus multicolor & Forest & 11164,11183 & 2 & Native \\
\hline & Gonyostomus goniostomus & Forest & 11120 & 1 & Native \\
\hline & Megalobulimus ovatus & Forest & 11136 & 2 & Native \\
\hline \multirow[t]{6}{*}{ Subulinidae } & Allopeas micra & Urban & $11126,11132,11141$ & 6 & Exotic \\
\hline & Allopeas gracile & Urban & 11127 & 2 & Exotic \\
\hline & Leptinaria unilamellata & Forest/Urban & $11109,11138,11142,11169,11193$ & $4 / 6$ & Exotic \\
\hline & Beckianum beckianum & Forest/Urban & $\begin{array}{c}\text { 11107, } 11128,11133,11153,11158 \\
11171,11194,11201\end{array}$ & $18 / 13$ & Exotic \\
\hline & Subulina octona & Urban & $11129,11140,11202,11206$ & 12 & Exotic \\
\hline & Freshwater species & & & & \\
\hline Planorbidae & Biomphalaria tenagophila & Urban & 11149,11196 & 105 & Native \\
\hline Ampullariidae & Pomacea sordida & Urban & 11147, 11152, 11187, 11191 & 34 & Native \\
\hline \multirow[t]{2}{*}{ Physidae } & Physa acuta & Urban & 11150,11197 & 89 & Exotic \\
\hline & Stenophysa marmorata & Urban & $11146,11151,11198$ & 13 & Native \\
\hline Thiaridae & Melanoides tuberculata & Forest/Urban & $11113,11125,11134,11186$ & $36 / 71$ & Exotic \\
\hline
\end{tabular}


and Veronicellidae. Among these species 15 were restricted to this area (Table I). The remaining species included mainly exotic or native synanthropic species, commonly found in disturbed and synantropic areas from Rio de Janeiro state (Table I). They were collected in the forest border near the headquarters of the CFMA and included two species of subulinids, Leptinaria unilamellata (Orbigny 1835) and Beckianum beckianum, the bulimulids Bulimulus tenuissimus (d'Orbigny 1835) and Tamayoa banghaasi, besides the freshwater snail M. tuberculata.

The terrestrial families with the highest number of samples in the Atlantic Forest (EFMA) were Neocyclotidae, Subulinidae and Simpulopsidae (Table I). The most found species in the area was the operculate Neocyclotus prominulus (d'Orbigny 1835) (31 samples) (Figures 2d, 7c), which was collected in the leaf litter on the woodland floor. The second most common species and exclusive of this area was the snail Leiostracus perlucidus (Spix 1827) (13 samples) (Figures 3i, 6c), followed by the operculate snail Helicina angulata Sowerby, 1873 (10 samples) (Figures 3g, 7f), both arboreal snails. Other arboreal species restricted to this
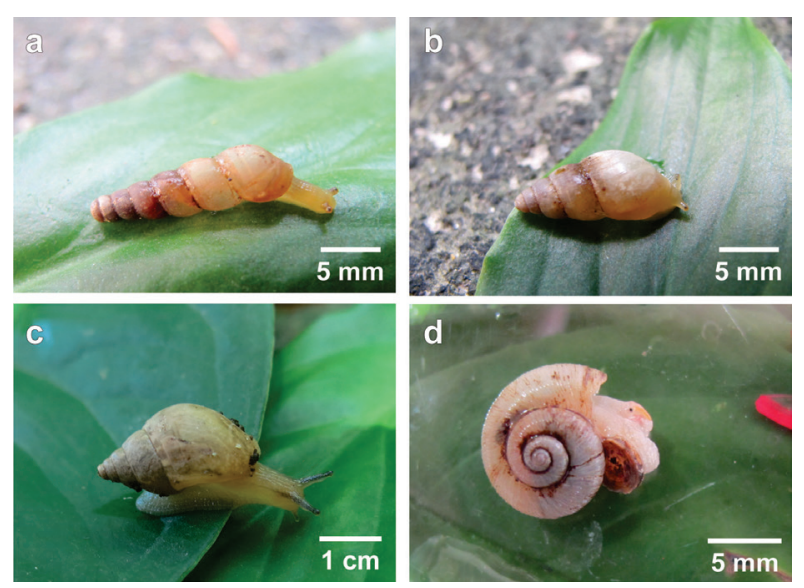

Figure 2. Alive specimens. a. Subulina octona (CMIOC 11202), b. Leptinaria unilamellata (CMIOC 11138), c. Bulimulus tenuissimus (CMIOC 11130), d. Neocyclotus prominulus (CMIOC 11160). area were Simpulopsis sulculosa (Férussac 1821) (Figures 3h, 6a) and Rhinus ciliatus (Gould 1846) (Figure 6d).

Another well-represented native species in the leaf litter was the megaspirid Megaspira elatior (Spix, 1827) (Figures 3d, 6g, h) that, however, was represented mainly by empty shells (8 samples), with only one specimen collected alive. The shell presents many whorls (the shell in the lengthiest specimen had 19 whorls, 49.66 $\mathrm{mm}$ in length and $7.93 \mathrm{~mm}$ in width). Adult specimens present three columellar lamellae and one parietal lamella in the aperture, which are not visible in the juvenile specimens (Figure $6 g)$. Surprisingly, when the soft body is retracted it occupies only the first whorls of the shell.

We also found some carnivorous species restricted to the Forest area. Two species of Scolodontidae were found in the leaf litter: Happia vitrina (Wagner 1827) (four shells) and Tamayoa banghaasi (Thiele 1927) (four shells), both small molluscs (Figure 7d, e). The largest specimen of $T$. banghaasi had a shell with 4.54 $\mathrm{mm}$ in width. Two species of Streptaxidae were also collected in the leaf litter: Rectartemon sp. and Streptaxis crossei (Pfeiffer 1867). Rectartemom sp. has a very characteristic orange body color and S. crossei has a peculiar small shell with eight whorls of similar diameter, and lamellae in the aperture (Figures 3e, 7b).

The largest native molluscs were found in the locality of Pau da Fome: Megalobulimus ovatus (Müller 1774) (Figures 3a, 8b) (two specimens), Thaumastus taunaisii (Férussac, 1821) (five specimens), (Figures 3b, 8c) and the slug Phyllocaulis boraceiensis Thomé, 1972 (one) (Figure $4 b$ ) that was found in activity on the ground, in a humid day. In addition, we found one specimen of the macromollusc Gonyostomus goniostomus (Férussac 1821) (Figures 3c, 8d) and a shell and a live specimen of Anthinus multicolor, which curiously was collected at the 

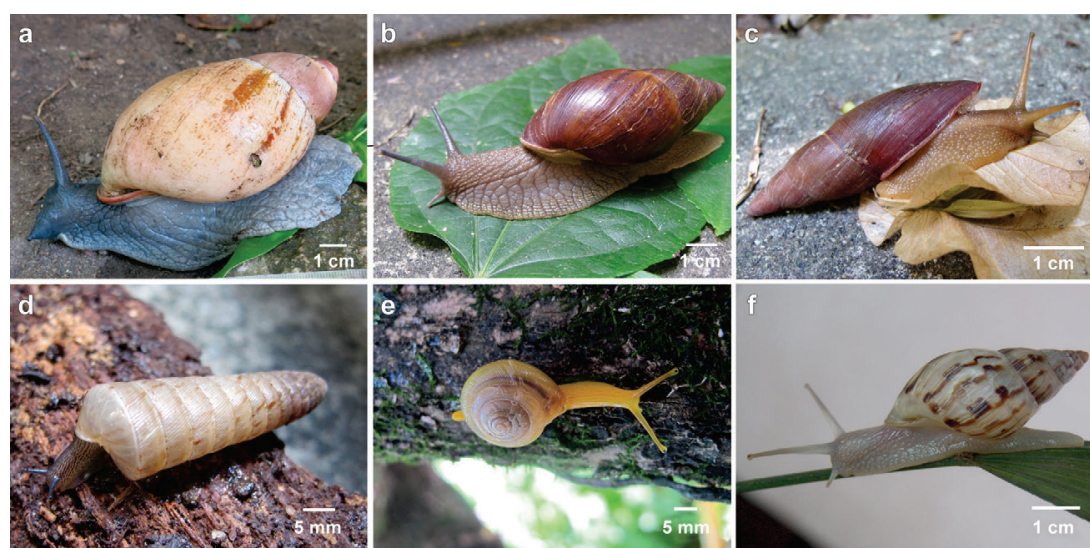

Figure 3. Alive specimens. a. Megalobulimus ovatus (CMIOC 11136), b. Thaumastus taunaisii (CMIOC 11135), c. Gonyostomus goniostomus (CMIOC 11120), d. Megaspira elatior (CMIOC 11161), e. Streptaxis sp. (CMIOC 11178),
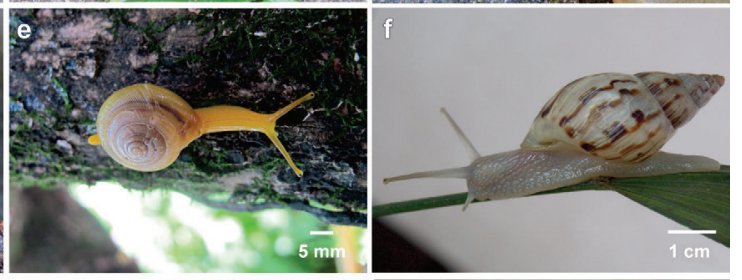
f. Drymaeus papyraceus (CMIOC 10005), g. Helicina angulata (CMIOC 11106), h. Simpulopsis sulculosa (CMIOC 11173), i. Leiostracus perlucidus (CMIOC 11122).
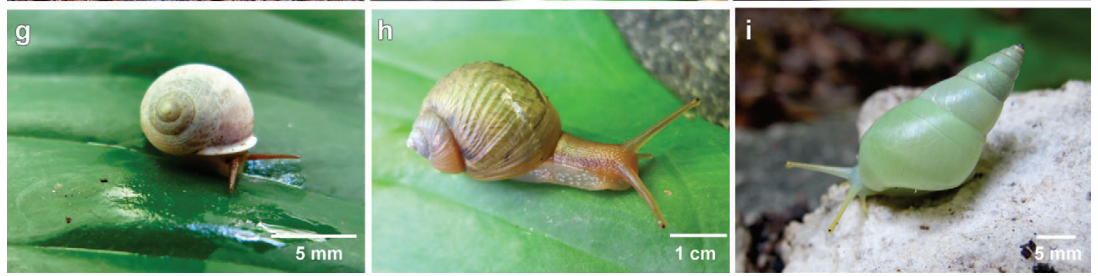

moment it was being eaten by a planarian (Figure 4a). They were photographed, but the planarian specimen become decomposed before being fixed and identified.

\section{Adjacent urban areas}

In total, 16 species were collected, including 11 land and five freshwater species (Table I). Parasitological analyzes of the following species: Achatina fulica, Pomacea sordida, Physa acuta (Draparnaud 1805), Stenophysa marmorata (Guilding 1828), Biomphalaria tenagophila (d'Orbigny 1835) and Melanoides tuberculata did not reveal infection with medically important nematodes and trematodes. Subulinidae was the most rep resentative family in the urban area, with five species found: Subulina octona (Brugüière, 1789), A. micrum, A. gracile, B. beckianum and $L$. unilamellata (Figures 2a, b, 5). All these species were widespread and were collected in urban gardens and forest borders. Two live specimens and 24 shells of $B$. tenuissimus were found in the urban area (Figures 2c, 6f).

A shell and a live specimen of the native and arboreous snail Drymaeus papyraceus (Mawe
1823) were also found in a garden and at the CFMA Headquarters, respectively (Figures 3f, 6b).

Two species of slugs were found in a domestic sewage ditch: two specimens of Latipes sp. (Veronicellidae), and three specimens of $D$. laeve (Figure 4c, d) (Agriolimacidae), which were collected under fallen trunks, in gardens and near the forest border (Table I).

Five freshwater species were collected (Table I): the planorbid Biomphalaria tenagophila (105 live specimens) (Figure 9e), the physid Stenophysa marmorata (13 live specimens) (Figure 9b), and live specimens of the ampullariid Pomacea sordida (33 specimens) (Figure 9c) from a domestic sewage ditch and a polluted stream. The other two species were exotic: Physa acuta collected in a garden drainage ditch (89 live specimens) that receives domestic sewage (Figure 9a), and the thiarid Melanoides tuberculata (71 live specimens) from a polluted stream (Figure 9d).

Two individuals of $B$. tenagophila (Figure 9e) were found parasitized by Xiphidiocercarie (Ubiquita) and 41 individuals of M. tuberculata were parasitized by Pleurolophocercus cercaria. 

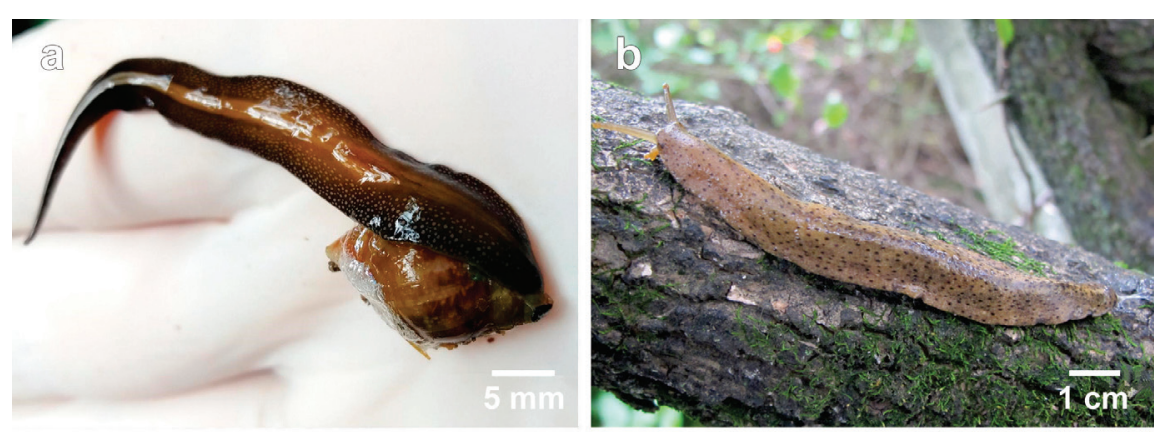

Figure 4. Alive specimens. a. Young Anthinus multicolor (CMIOC 11116) being eaten by a planarian. b. Phyllocaulis boraceiensis (CMIOC 11203). c. Latipes sp. (CMIOC 11145), d. Deroceras laeve (CMIOC 11200).
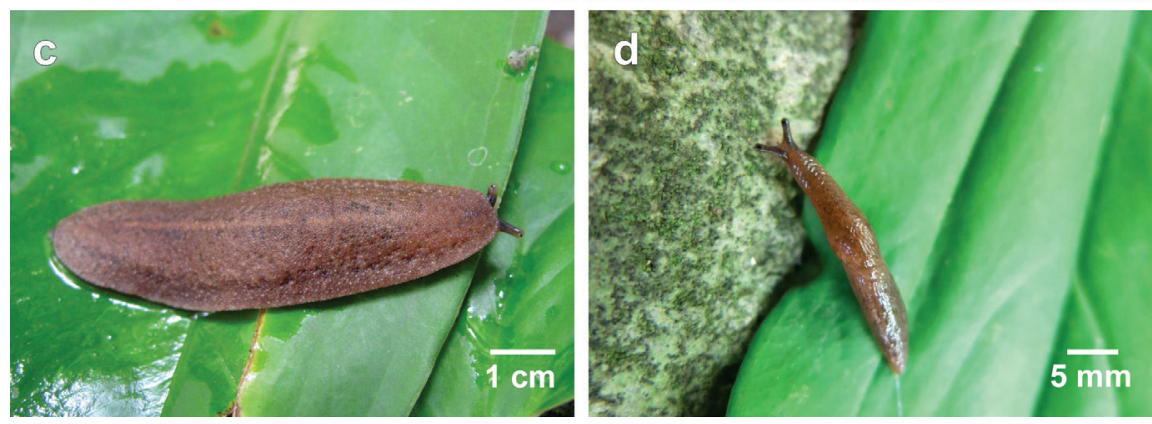

a

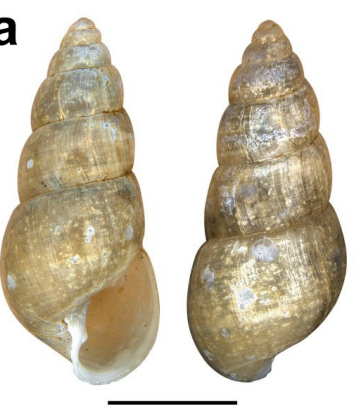

c

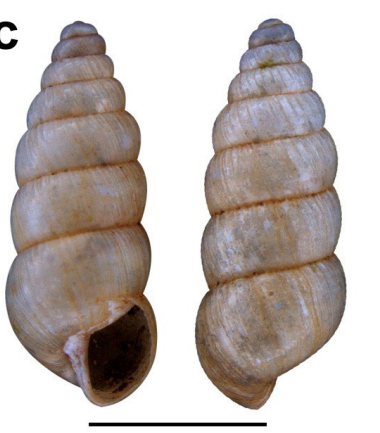

b

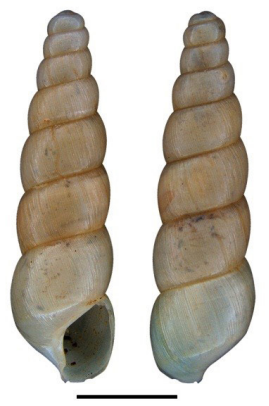

d

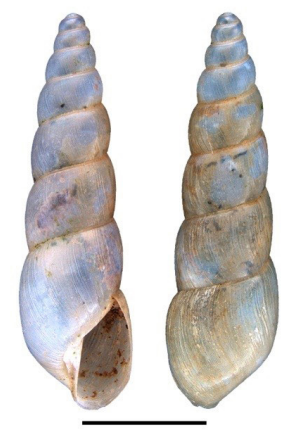

Figure 5. Shell in different views. a. Leptinaria unilamellata (CMIOC 11138), b. Subulina octona (CMIOC 11129), c. Beckianum beckianum (CMIOC 11133), d. Allopeas gracile (CMIOC 11127), e. Allopeas micrum (CMIOC 11126). Scale: $5 \mathrm{~mm}$.

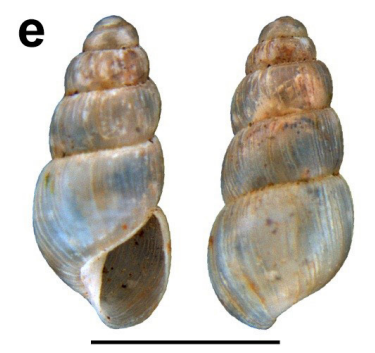




\section{DISCUSSION}

The biodiversity of molluscs found in the present study is high in view of the short sampling period, and the relatively small sampled area. Twelve families of terrestrial molluscs and four of freshwater were found. The number of species of land molluscs was lower in the urban area (11 species), although more freshwater species (five species) and water bodies were investigated in this area in relation to the Forest area. Similarly, Alexandre et al. (2017) carried out a survey of the Urca campus of the Universidade Federal do Estado do Rio de Janeiro, which is bordered by
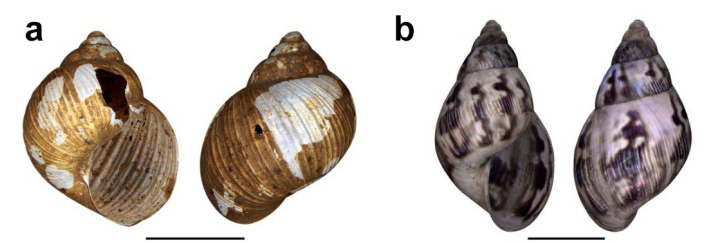

C

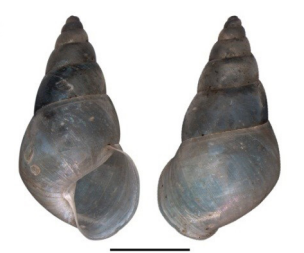

e

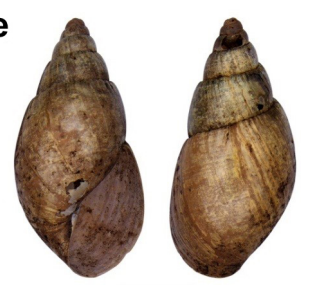

g
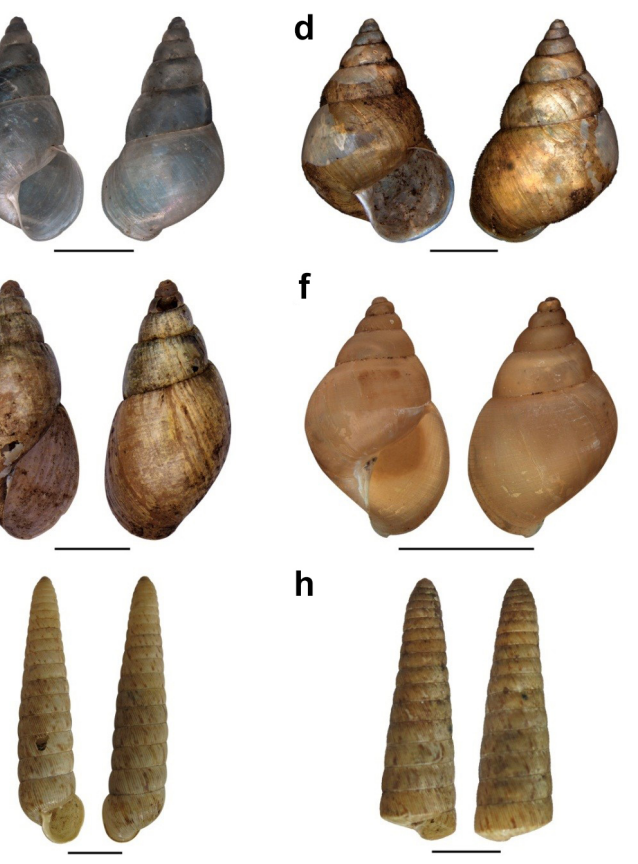

f

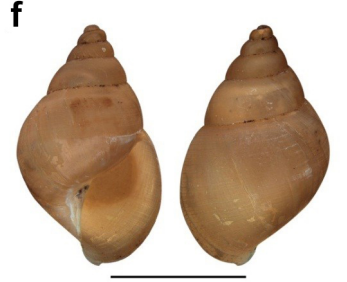

h

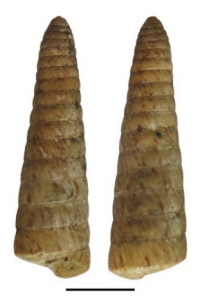

Figure 6. Shell in different views. a. Simpulopsis sulculosa (CMIOC 11173), b. Drymaeus papyraceus (CMIOC 11148), c. Leiostracus perlucidus (CMIOC 11154), d. Rhinus ciliatus (CMIOC 11163), e. Lopesianus crenulatus (CMIOC 11159), f. Bulimulus tenuissimus (CMIOC 11123), g-h. Megaspira elatior adult (g) and younger (h) (CMIOC 11161). Scale: $1 \mathrm{~cm}$.

Parque Natural Municipal da Paisagem Carioca and is within the buffer zone of Monumento Natural dos Morros do Pão de Açúcar e da Urca (MONA), and found 18 species and 12 families. Peres (2019) developed a similar study in São Paulo state and reported 13 species in a survey of malacofauna in an Atlantic Forest area with similar characteristics (Carmo Park, São Paulo). Simpulopsis sulculosa was the only species found in both studies.

In the present study was possible to distinguish two communities of species, one in the forest and another in the urbanized area. Fifteen species were restricted to the forest area and N. prominulus, L. perlucidus and $H$. angulata, were among the most common species. The Caenogastropoda N. prominulus was found only in the forest leaf litter. It is reported from Paraná, São Paulo, Rio de Janeiro and Minas Gerais States (Simone 2006). Santos \& Monteiro (2001) reported that $N$. prominulus was only found in the most preserved area of the Atlantic Forest in the locality of Vila Dois Rios, in Ilha Grande, State of Rio de Janeiro, where there was no human occupation. Santos et al. (2009) aiming the conservation of both terrestrial molluscs and the Atlantic Forest proposed the species $L$. perlucidus as one of the umbrella or flag species. Helicina angulata, which is another Caenogastropoda, is recorded to the states of Rio de Janeiro, São Paulo and Bahia (Simone 2006).

We highlight the occurrence of some large molluscs in the Atlantic Forest area, as $M$. ovatus, that ranges from the coast of Rio de Janeiro to Santa Catarina (Simone 2006) and G. goniostomus, which has a smaller and slender shell (Figure 8d). According to Leme (1973) Gonyostomus Beck, 1837 is endemic to Southeast Brazil, inhabiting tropical and humid forests, with species rarely collected. Thaumastus taunaisii, whose largest specimen had a shell reaching 7.2 
a
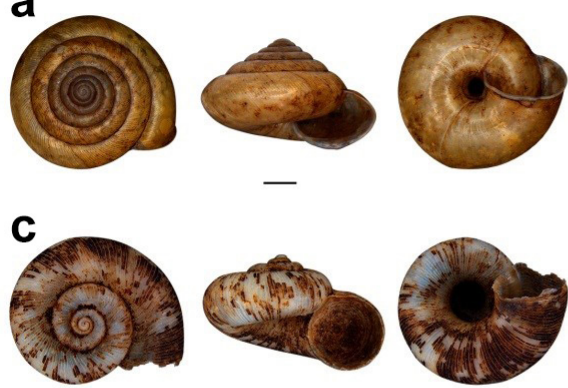

-
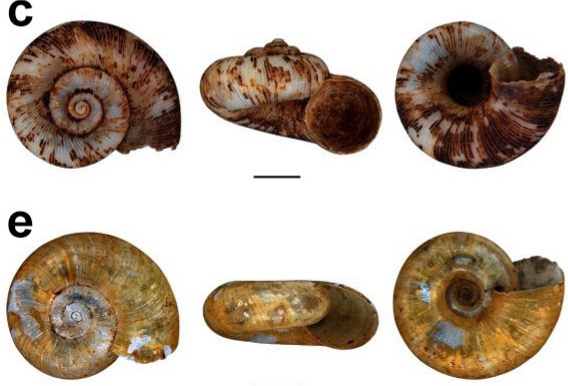

b

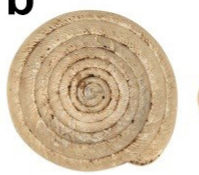

d
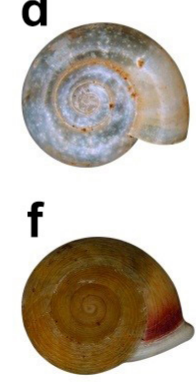
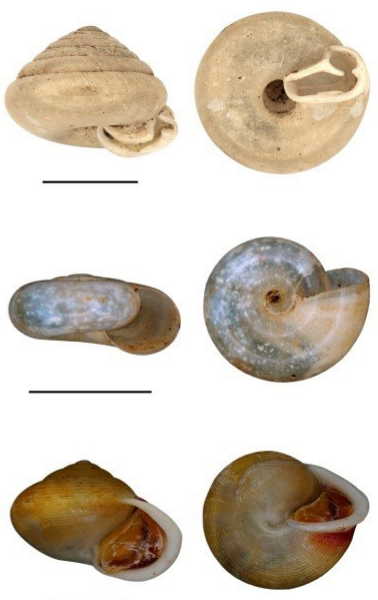

Figure 7. Shell in different views. a. Streptaxis sp. (CMIOC 11649), b. Streptaxis crossei (CMIOC 11182), c. Neocyclotus prominulus (CMIOC 11160), d. Tamayoa banghaasi (CMIOC 11131), e. Happia vitrina (CMIOC 11650), f. Helicina angulata (CMIOC 11106). Scale: $5 \mathrm{~mm}$. $\mathrm{cm}$ in length and $3.0 \mathrm{~cm}$ in diameter, is reported to the states of Santa Catarina, São Paulo, Minas Gerais and Rio de Janeiro (Salgado et al. 1995, Simone 2006). The slug P. boraceiensis is reported to southeastern Brazil, in the states of Minas Gerais, Rio de Janeiro, São Paulo, Paraná and Santa Catarina (Thomé 1972, Thomé et al. 2006, Simone 2006) and it is considered the largest species of Veronicellidae (more than 20 cm in length) (Thomé 1972, Thomé et al. 2006).

Despite being a native species from Atlantic forest areas, including Rio de Janeiro that is its type-locality, the arboreous snail Drymaeus papyraceus was only found in the urban area, although the species probably also occurs in the PEPB. The species is widespread in Brazil, being reported to Paraíba, Pernambuco, Alagoas, Bahia, Espírito Santo, Rio de Janeiro, Paraná and Rio Grande do Sul (Rezende 1975, DutraClarke \& Souza 1991, Silva \& Castro 2003). Other countries where the species occurs are Paraguay, Argentina and Uruguay (Simone 2006). On the other hand, some species found in the Forest area, have a more restricted distribution, as $R$. ciliatus, M. elatior and G. goniostomus, which are so far reported only from the state of Rio de Janeiro (Simone 2006). Bulimulus tenuissimus, T. banghaasi and the subulinids A. micra, $L$. unilamellata and B. beckianum, besides $M$. tuberculata, were collected in both areas. Most are common in disturbed and urban areas from Rio de Janeiro State (Santos et al. 2010, Alexandre et al. 2017), and found in disturbed and preserved areas from other Brazilian States (Simone \& Cesati 2013, Salvador et al. 2018, Ramos-de-Souza et al. 2018, Coelho et al. 2018, Silva et al. 2019).

Some species found in the urban areas were already naturally found hosting the nematodes Angiostrongylus cantonensis (Chen, 1935) and Angiostrongylus costaricensis Morera \& Céspedes, 1971, which cause eosinophilic meningitis and/or abdominal angiostrongyliasis, respectively (Ohlweiler et al. 2010, Morassutti et al. 2014). They were S. octona (infected by $A$. cantonensis), B. tenuissimus ( $A$. cantonensis), A. fulica (A. cantonensis) and D. laeve (A. costaricensis) (Ohlweiler et al. 2010, Ramos-de-Souza et al. 2018). We call attention to the two last species since they are important agricultural and urban pests. Achatina fulica has been introduced in several parts of the world including Brazil, where it is very widespread and considered an urban pest (Thiengo et al. 2007). It has been associated with the expansion of eosinophilic meningitis in Brazil (Morassutti et al. 


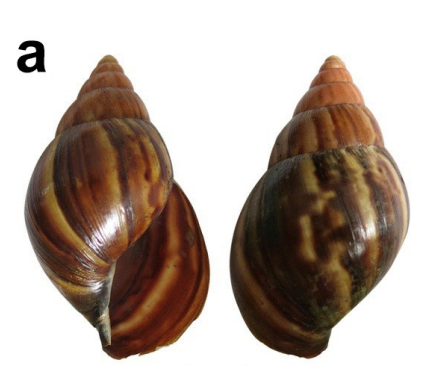

$\overline{1 \mathrm{~cm}}$

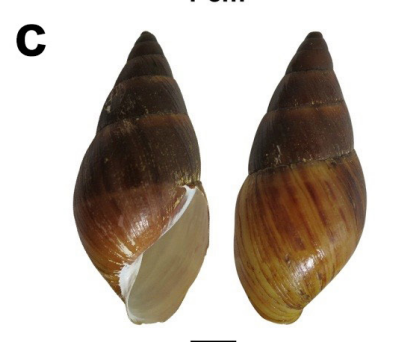

$\overline{1 \mathrm{~cm}}$

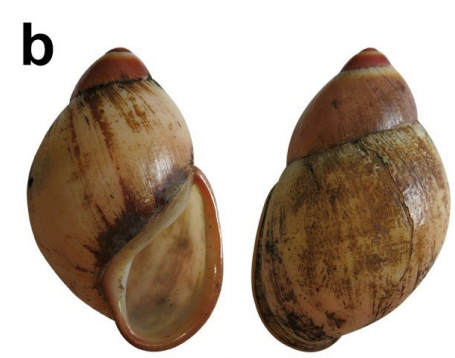

$1 \overline{\mathrm{cm}}$
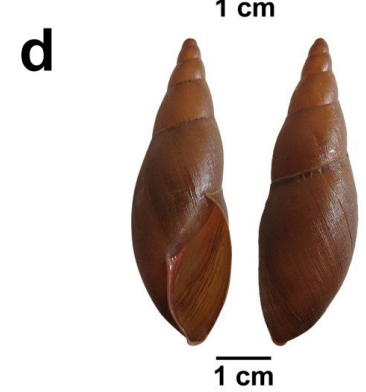

Figure 8. Shell in different views. a. Achatina fulica (CMIOC 11205), b. Megalobulimus ovatus (CMIOC 11136), c. Thaumastus taunaisii (CMIOC 11135), d. Gonyostomus goniostomus (CMIOC 11120), e. Anthinus multicolor (CMIOC 11164). Scale: $1 \mathrm{~cm}$.

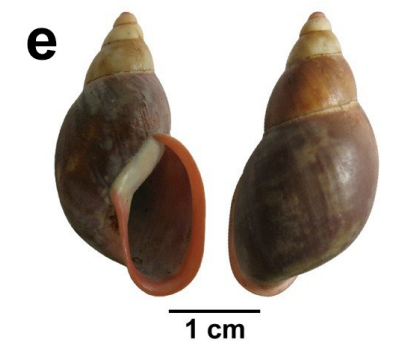

2014, Thiengo \& Fernandez 2016). Deroceras laeve is a cosmopolitan species, described originally from Europe and accidentally introduced to various parts of Brazil and the world (Barker 1999, Ohlweiler et al. 2010). It is considered a horticultural and garden pest (Barker 1999). Maurer et al. (2002) emphasized the potential of $D$. laeve as transmitter of parasites due to the small size of this slug that is often found between vegetable leaves and can easily be accidentally ingested.

Subulinidae and Bulimulidae were the most diverse families and found in the preserved forest area and in the urban area. The same was observed by other authors such as Lopes et al. (2012) in the state of Rio de Janeiro. Subulinidae was also the most diverse family in the campus of the Centro Universitário CIDADE (Madureira neighborhood), Rio de Janeiro city, where four species were found according to Alexandre et al. (2017). In the present study five species were found: L. unilamellata, S. octona, $A$. micrum, A. gracile and B. beckianum. Leptinaria unilamellata is considered cosmopolitan, with distribution expanded mainly by anthropic action (Araújo 1982). In Brazil, it occurs in the states of Amazonas, Pará, Rondônia, Mato Grosso, Alagoas, Pernambuco, Bahia, Minas Gerais, Rio de Janeiro, São Paulo, Paraná, Santa Catarina and Rio Grande do Sul (Morretes 1949, Araújo 1982, Agudo-Padrón 2008, Araújo \& Keller 1993, Salvador et al. 2018, Silva et al. 2019). According to Cowie et al. (2017), Allopeas micrum has a natural distribution in the Caribbean, Central and North America. In Rio de Janeiro, that is the type-locality of A. micrum, this species, as well as other subulinids, is found in anthropic and/or urbanized areas (Lopes et al. 

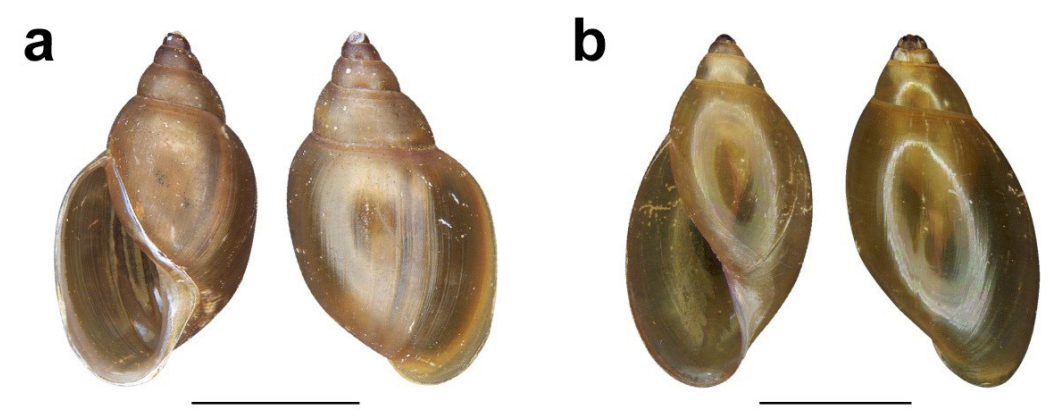

Figure 9. Shell in different views. a. Physa acuta (CMIOC 11150), b. Stenophysa marmorata (CMIOC 11198), c. Pomacea sordida (CMIOC 11147), d. Melanoides tuberculata (CMIOC 11186), e. Biomphalaria tenagophila (CMIOC 11149). Scale: $5 \mathrm{~mm}$.

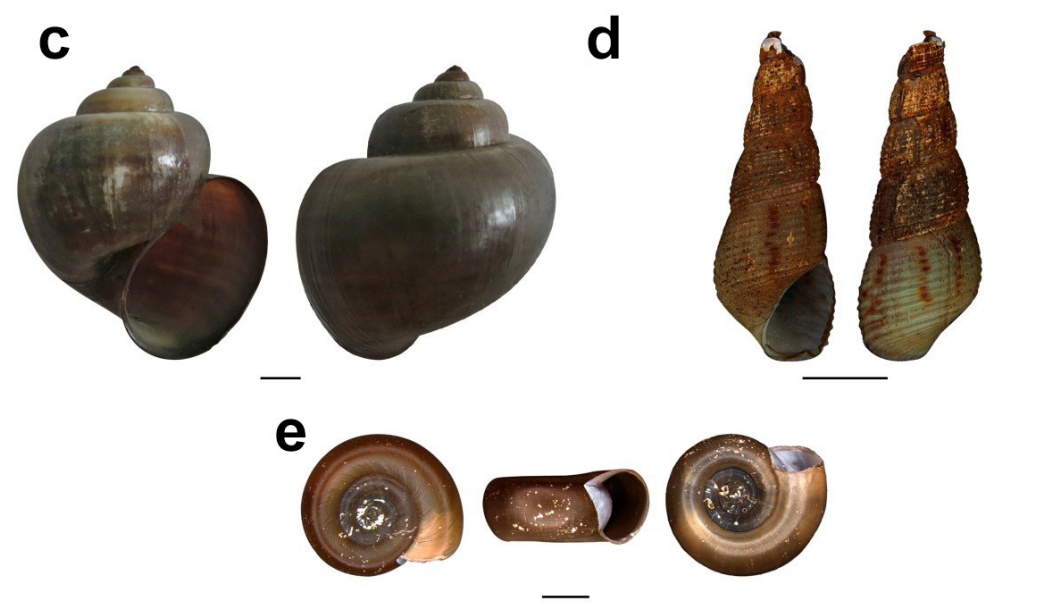

Santos \& Monteiro (2001) examined different 2012). Allopeas gracile is widely distributed in levels of anthropic influence in two areas of tropical and subtropical areas of Asia, Australia, and Polynesia, as well as Central and South America (Capinera 2017). Its exact origin is not known, although Capinera (2017) suggested that it is South America. According to Santos et al. (2010) A. gracile is a synanthropic species, and it can live in habitats with lower humidity as other synantropic subulinids. Beckianum beckianum has a wide distribution in the American continent and Caribbean Islands. It is reported to Mexico, Central America (continent and some islands) and South America (Colombia, Venezuela, Brazil and Peru) (Simone 2006, Velázquez et al. 2010). In Brazil, $B$. beckianum is also widespread: states of Pará, Fernando de Noronha, Rio Grande do Norte, Roraima, Bahia, Rio de Janeiro and São Paulo (Birckolz et al. 2016). Atlantic Forest in Ilha Grande, RJ, and analyzed the relationship between the malacofauna diversity in relation to the anthropic effect and the environmental heterogeneity in the studied areas. They reported the presence of $B$. beckianum (Subulinidae) as a possible indicator of anthropic influence in the Jararaca Trail in the locality of Vila Dois Rios, Ilha Grande.

Regarding the freshwater species, the highest number of species was found in the urbanized area, where more sites were sampled. Of the eight species of gastropods mentioned by Santos et al. (2003) for the Pedra Branca State Park, four were collected in the present study: M. tuberculata, P. acuta, B. tenagophila and $P$. sordida. Thiengo et al. (2001) reported B. tenagophila to Vargem Grande, and other 



\author{
Figure 10. Two collection \\ sites. a. Site at the \\ forest area near the \\ main trail. b. Site \\ at polluted stream \\ Caminho da Cachoeira.
}

of the Rio de Janeiro city and pointed out the infection with Xiphidiocercariae in this species. This was the first record of this association in Brazil, followed by Bogéa et al. (2005) also in Rio de Janeiro and by Pinto \& Melo (2010) in the Belo Horizonte city, state of Minas Gerais. Adults of Xiphidiocercarie are parasitic of the intestine of birds and in the Pleurolophocercus cercarian type included Centrocestus formosanus. The latter parasites the intestine of birds and mammals including humans, in which they cause centrocestiasis. Although this zoonosis is endemic to Asian countries, M. tuberculata was already reported infected by this cercaria in Brazil (Pinto \& Melo 2010).

Pomacea sordida was previously reported to Duque de Caxias and Nova Iguaçu municipalities (Thiengo 1989). It is an endemic species of the state of Rio de Janeiro that is included in the List of Endangered Fauna of Rio Janeiro (ICMBio 2016).

\section{CONCLUSIONS}

Our results demonstrate that even small area assessments can reveal an extraordinary diversity of non-marine gastropods. It was possible to identify two different gastropod communities. The occurrence of many native species in the preserved area and intermediate hosts in the adjacent urban area demonstrate the relevance of this research, which may help in the conservation of local biodiversity and public health policies. However, considering the great diversity of endemic molluscs found in a relatively small part of the EFMA and PEPB, we highlight the need for additional and continuous studies in both areas.

\section{Acknowledgments}

We are indebted to Dr. Ricardo Moratelli and his staff for facilitating access to study sites and for support during the field trips. To Dr. Norma Salgado (in memorian) for the helpful assistance with the terrestrial mollusc identification. To the graphic designer Eduardo Cinilha for the photos and figures editions. To Nilson Azevedo Pires, Claudio Pedroso Aboud and Marcelo José Pereira for their fundamental collaboration with the fieldwork and donation of mollusc samples.

\section{REFERENCES}

AGUDO-PADRÓN Al. 2008. Listagem sistemática dos moluscos continentais ocorrentes no estado de Santa Catarina, Brasil. Comun Soc Malacol Urug 9(91): 147-179.

ALEXANDRE GDL, DAMASCENO HV, MIYAHIRA IC \& CAETANO CHS. 2017. Gastrópodes (Mollusca) presentes no campus Urca 
da Universidade Federal do Estado do Rio de Janeiro (UNIRIO). Biotemas 30: 31-40.

ALTAF J, QURESHI NA \& SIDDIQUI MJI. 2017. Terrestrial snails aS bioindicators of environmental degradation. J Biodivers Environ Sci 10: 253-264.

ARAÚJO JLB. 1982. Alguns moluscos terrestres como hospedeiros intermediários de parasitas de animais domésticos, no Brasil: estudos sobre a anatomia, sistemática e participação em helmintoses. Universidade Federal Rural do Rio de Janeiro: Itaguaí, 103 p.

ARAÚJO JLB \& KELLER DG. 1993. Moluscos de importância econômica no Brasil. 11l. Subulinidae, Leptinaria unilamellata (Orbigny) (Mollusca, Gastropoda, Pulmonata, Stylommatophora). Rev Bras Zool 10(3): 499-507.

BARKER GM. 1999. Naturalised terrestrial Stylommatophora (Mollusca: Gastropoda) fauna of New Zealand. Manaaki Whenua Press, Lincoln, Canterbury: New Zealand, 253 p.

BARKER GM. 2002. Molluscs as crop pests. CABI publishing, Wallingford, $469 \mathrm{p}$.

BIRCKOLZ CJ, SALVADOR RB, CAVALLARI DC \& SIMONE LRL. 2016. Illustrated checklist of newly described (2006-2016) land and freshwater Gastropoda from Brazil. Archiv für Molluskenkunde 145(2): 133-150.

BOGÉA T, CORDEIRO FM \& GOUVEA JC. 2005. Melanoides tuberculatus (Gastropoda: Thiaridae) as intermediate host of Heterophyidae (Trematoda: Digenea) in Rio de Janeiro metropolitan area, Brazil. Rev Inst Med Trop 47: 87-90.

BOUCHET P, ROCROI JP, HAUSDORF B, KAIM A, KANO Y, NÜTZEL A, PARKHAEV P, SCHRÖDL M \& STRONG EE. 2017. Revised classification, nomenclator and typification of gastropod and monoplacophoran families. Malacologia 61(1-2): 1-526.

BREURE ASH \& ABLETT JD. 2011. Annotated type catalogue of the Amphibulimidae (Mollusca, Gastropoda, Orthalicoidea) in the Natural History Museum, London. ZooKeys 138: 1-52.

BREURE ASH \& ABLETT JD. 2012. Annotated type catalogue of the Bothriembryontidae and Odontostomidae (Mollusca, Gastropoda, Orthalicoidea) in the Natural History Museum, London. ZooKeys 182: 1-70.

BREURE ASH \& ABLETT JD. 2014. Annotated type catalogue of the Bulimulidae (Mollusca, Gastropoda, Orthalicoidea) in the Natural History Museum, London. ZooKeys 392: 1-367.

BREURE ASH \& ABLETT JD. 2015. Annotated type catalogue of the Megaspiridae, Orthalicidae, and Simpulopsidae (Mollusca, Gastropoda, Orthalicoidea) in the Natural History Museum, London. ZooKeys 470: 17-143.
BREURE ASH \& ARAÚJO R. 2016. The Neotropical land snails (Mollusca, Gastropoda) collected by the 'Comisión Científica del Pacífico'. PeerJ Preprints 5: 1-108.

CAPINERA JL. 2017. Biology and food habits of the invasive snail Allopeas gracile (Gastropoda: Subulinidae). Fla Entomol 100(1): 116-123.

COELHO PN, FERNANDEZ MA, CESAR DAS, RUOCCO AMC \& HENRY R. 2018. Update distribution and range expansion of the gastropod invader Melanoides tuberculate (Müller 1774) in Brazilian waters. Bioinvasions Rec 7: 405-409.

COWIE RH, RUNDELL R \& YEUNG NW. 2017. Samoan Land Snail and Slugs. A identification guide. Department of Marine and Wildlife Resources, American Samoa Government, $71 \mathrm{p}$.

DREVES AJ, ANDERSON N \& SULLIVAN C. 2017. Slug Control In: Pacific Northwest Insect Management Handbook. Oregon State University. Hollingsworth CS (Ed), p. 14-16.

DUTRA-CLARKE AVC \& SOUZA FBVA. 1991. Bulimulidae (Gastropoda, Stylommatophora) do nordeste do Brasil. Rev Bras Zool 7(3): 289-304.

FERNANDEZ MA, THIENGO SC \& SIMONE LRL. 2003. Distribution of the introduced freshwater snail Melanoides tuberculatus (Gastropoda: Thiaridae) in Brazil. The Nautilus 117: 78-82.

FUKUDA H, HAGA T \& TATARA Y. 2008. Niku-nuki: a useful method for anatomical and DNA studies on shell-bearing. Zoosymposia 1: 15-38.

GRAEFF-TEIXEIRA C \& MORERA P. 1995. Método de digestão de moluscos em ácido clorídrico para isolamento de larvas de Metastrongilídeos. Biociências 3: 85-89.

INEA. 2013. Plano de Manejo do Parque Estadual da Pedra Branca. Rio de Janeiro. http://www.femerj.org/ wp-content/uploads/Plano-de-manejo-do-ParqueEstadual-da-Pedra-Branca-PEPB-2.pdf. Acessed on November 30, 2017.

ICMBio - INSTITUTO CHICO MENDES DE CONSERVAÇÃO DA BIODIVERSIDADE. 2016. Sumário executivo do Livro Vermelho da fauna brasileira ameaçada de extinção. http://www.icmbio.gov.br/portal/images/stories/ comunicacao/publicacoes/publicacoesdiversas/dcom_ sumario_executivo_livro_vermelho_da_fauna_brasileira_ ameacada_de_extincao_2016.pdf. Acessed on March, 3, 2018.

KAPPES H, JORDEANS $\mathrm{K}$, HOUTTE NV, HENDRICKX F, MAELFAIT JP, LENS L \& BACKELIJAU T. 2009. A land snail's view of a fragmented landscape. Biol J Linn Soc Lond 98: 839-850.

LEME JLM. 1973. Anatomy and systematics of the Neotropical Strophocheiloidea (Gastropoda, Pulmonata) with the description of a new family. Arq Zool 23: 295-337. 
LOPES MPAM, NUNES GKM \& DOS SANTOS SB. 2012. Levantamento preliminar da malacofauna do Campus do Centro Universitário da Cidade (Univercidade, Unidade Madureira), Rio de Janeiro, RJ. XXIII EBRAM 43: 2-6.

MAURER RC, GRAEFF-TEIXEIRA C, THOMÉ JW, CHIARADIA LA, SUGAYA H \& YOSHIMURA K. 2002. Natural Infection of Deroceras laeve (Mollusca: Gastropoda) With Metastrongylid larvae in a Transmission Focus of Abdominal Angiostrongyliasis. Rev Inst Med Trop de São Paulo 44: 53-54.

MMA - MINISTÉRIO DO MEIO AMBIENTE. 2006. Espécies exóticas invasoras: situação brasileira. Brasília: MMA / Ministério do Meio Ambiente, 24 p.

MORASSUTTI AL, THIENGO SC, FERNANDEZ M, SAWANYAWISUTH K \& GRAEFF-TEIXEIRA C. 2014. Eosinophilic meningitis caused by Angiostrongylus cantonensis: an emergent disease in Brazil. Mem Inst Oswaldo Cruz 109: 399-407.

MORRETES FL. 1949. Ensaio de Catálogo dos Moluscos do Brasil. Arquivos do Museu Paranaense: Curitiba, 363 p.

MS - MINISTÉRIO DA SAÚDE. 2008. Secretaria de Vigilância em Saúde. Departamento de vigilância epidemiológica. 2008. Vigilância e Controle de Moluscos de Importância médica: Diretrizes técnicas: Programa de Vigilância e Controle da Esquitossomose (PCE). 2a ed., Brasília: Editora MS, 178 p.

NICOLAI A \& ANSART A. 2017. Conservation at a slow pace: terrestrial gastropods facing fast-changing climate. Conserv Physiol 5(1): 1-17.

OHLWEILER FP, TAKAHASHI FY, GUIMARÃES MCA, GOMES SR \& KAWANO T. 2010. Manual de gastrópodes límnicos e terrestres do estado de São Paulo associados às helmintoses. Rede Editora: Porto Alegre, RS, 224 p.

PERES ICS. 2019. Levantamento de Malacofauna Terrestre e Dulcícola do Parque do Carmo, no Município de São Paulo (SP). Rev Cie Mul Núcleo do Conhecimento 2: 117-133.

PINTO HA \& MELO AL. 2010. Melanoides tuberculata (Mollusca: Thiaridae) as an Intermediate Host of Centrocestus formosanus (Trematoda: Heterophyidae) in Brazil. Rev do Inst Med Trop de São Paulo 52: 207-210.

PINTO HA \& MELO AL. 2013. Larvas de Trematódeos em Moluscos do Brasil: Panorama e Perspectivas após um Século de Estudos. Rev Patol Trop 42: 369-386.

QGIS DEVELOPMENT TEAM. 2017. QGIS Geographic Information System. Open Source Geospatial Foundation Project. http://www.qgis.org/.

RAMOS-DE-SOUZA J, THIENGO SC, FERNANDEZ MA, GOMES SR, ANTÔNIO JC, CLIIMACO MC, GARCIA JS, MALDONADO-JUNIOR A, BARBOSA L \& DOLABELLA SA. 2018. First records of mollusCS naturally infected with Angiostrongylus cantonensis (Nematoda: Metastrongyloidea) in Sergipe state, northeastern Brazil, including new global records of natural intermediate hosts. Rev do Inst Med Trop de São Paulo 60: 1-7.

SALGADO NC, COELHO AC \& BARROS HM. 1995. Macroanatomia, microanatomia e histologia do sistema reprodutor de Thaumastus (Thaumastus) taunaisii (Férussac, 1822), T. (T.) magnificus (Grateloup, 1839) e T. (T.) achilles (Pfeiffer, 1852) (Mollusca, Gastropoda, Bulimulidae). Bol Mus Nac 358: 1-46.

SANTOS SB, MAGALHÃES-FRAGA SAP, BRAUN BS \& MOULTON TP. 2003. The first list of freshwater molluscs to the "Pedra Branca State Park". Biociencias 11(2): 185-186.

SANTOS SB, MAYHÉ-NUNES AJ, BROWN G, COSTA JM, LUZ JL, LORENZON MCA, SALGADO NC, CERQUEIRA RLB \& MONTEIRO R. 2009. Conservação dos invertebrados terrestres no Estado do Rio de Janeiro In: Estratégias e ações para a conservação da biodiversidade no Estado do Rio de Janeiro (Bergallo HG, Fidalgo ECC, Rocha CFD, Uzêda MC, Costa MB, Alves MAS, Van Sluys M, Santos MA, Costa, TCC \& Cozzolino AC Eds) Instituto Biomas, Rio de Janeiro, p. 127-152.

SANTOS SB \& MONTEIRO OP. 2001. Composição de gastrópodes terrestres em duas áreas do Centro de Estudos Ambientais e Desenvolvimento Sustentado (CEADS), Vila Dois Rios, Ilha Grande, Rio de Janeiro, Brasil - um estudo-piloto. Rev Bras Zool 18: 181-190.

SANTOS SB, RODRIGUES CL, NUNES GKM, BARBOSA AB, LACERDA LEM, MIYAHIRA IC, VIANA TA, OLIVEIRA JL, FONSECA FC \& SILVA PSC. 2010. Estado do conhecimento da fauna de invertebrados não-marinhos da Ilha Grande (Angra dos Reis, RJ). Oecol Aust 14: 504-549.

SICILIANO WC, BASTOS GP, OLIVEIRA IT, SILVA GNS, OBRACZKA M \& OHNUMA AA. 2018. Variabilidade espacial e temporal da precipitação pluvial no município do Rio de Janeiro. RIC 8(2): 221-233.

SILVA CC \& CASTRO GA. 2003. Gastrópodes terrestres num fragmento de restinga do Estado do Espírito Santo. Biokos 17: 65-69.

SILVA FS, SIMONE LRL \& SALVADOR RB. 2019. Taxonomic study on a collection of terrestrial mollusks from the region of Santa Maria, Rio Grande do Sul state, Brazil. Arq Zool 50(3): 175-190.

SIMONE LRL. 2006. Land and freshwater mollusc of Brazil. São Paulo: FAPESP, 390 p.

SIMONE LRL \& CASATI R. 2013. New land mollusk fauna from Serra da Capivara, Piauí, 930 Brazil, with a new genus and five new species (Gastropoda: Orthalicoidea, 931 Streptaxidae, Subulinidae). Zootaxa 3683(2): 145-158.

SOUZA NA, SILVA JB, GODOY RE, SOUZA FJM, ANDRADE-COELHO CA, SILVA VC, AZEVEDO ACR \& RANGEL EF. 2015. Studies on Phlebotominae (Diptera: Psychodidae) in the Campus 
FIOCRUZ Mata Atlântica, Jacarepaguá, in the City of Rio de Janeiro, Brazil. Rev Soc Bras Med Trop 48: 26-32.

THIENGO SARC, HAYES KA, MATTOS AC \& FERNANDEZ MLA. 2011. A Família Ampullariidae no Brasil: Aspectos Morfológicos, Biológicos e Taxônomicos. In: Fernandez MLA, Santos SB, Pimenta AD \& Thiengo SACT (Org). Tópicos em Malacologia (Ecos do XIX Encontro Brasileiro de Malacologia). Rio de Janeiro: Technical Books 1: 93-109.

THIENGO SC. 1989. On Pomacea sordida (Swainson, 1823) (Prosobranchia, Ampullariidae). Mem Inst Oswaldo Cruz 84: 351-355.

THIENGO SC, FARACO FA, SALGADO NC, COWIE RH \& FERNANDEZ MA. 2007. Rapid spread of an invasive snail in South America: the giant African snail, Achatina fulica, in Brasil. Biol Invasions 9: 693-702.

THIENGO SC \& FERNANDEZ MA. 2016. Moluscos como hospedeiros intermediarios de Angiostrongylus cantonensis em Brasil. In: Angiostrongylus cantonensis: Emergencia em América, La Habana. In: Robles LM \& Contreras AJD, p. 270-276.

THIENGO SC, FERNANDEZ MA, BOAVENTURA MF, GRAULT CE, MATTOS AC \& SANTOS SB. 2001. Freshwater Snails and Schistosomiasis Mansoni in the State of Rio de Janeiro, Brazil: I - Metropolitan Mesoregion. Mem Inst Oswaldo Cruz 96: 177-184.

THIENGO SC, FERNANDEZ MA \& MATTOS AC. 2012. Malacologia. In: Conceitos e métodos para a formação de profissionais em laboratórios de saúde, 5., Rio de Janeiro. In: Molinaro EM, Caputo LFG \& Amendoeira MRR, p. 413-475.

THOMÉ JW. 1972. Uma nova espécie de Phyllocaulis do Brasil - (Veronicellidae, Gastropoda). Iheringia 41: 59-68.

THOMÉ JW. 1975. Distensão de moluscos terrestres para fixação, com comentários sobre coleta e transporte. Arch Mus Nac 55: 153-154.

THOMÉ JW, GOMES SR \& PICANÇO JB. 2006. Guia ilustrado: OS caracóis e as lesmas dos nossos bosques e jardins. USEB, $123 \mathrm{p}$.

VELÁZQUEZ AF, FRANKE S \& GUTIÉRREZ PG. 2010. Primer registro de Beckianum beckianum (Gastropoda: Subulinidae) para la Región Centro Oriental de Cuba. Cocuyo 18: 35-37.

\section{How to cite}

RANGEL FCS, GOMES SR, CANUTO T, RODRIGUES PS \& THIENGO SC. 2021. Diversity of non-marine gastropods of the Fiocruz Atlantic ForestBiological Station and adjacents urban areas, Rio de Janeiro, RJ, Brasil. An Acad Bras Cienc 93: e20190691. DOI 10.1590/00013765202120190691.
Manuscript received on June 14, 2019;

accepted for publication on January 27, 2020

\section{FLAVIA C.S. RANGEL}

https://orcid.org/0000-0003-3164-0871

\section{SUZETE R. GOMES}

https://orcid.org/0000-0002-5552-5053

\section{THAMIRES CANUTO}

https://orcid.org/0000-0001-7278-9547

PAULO S. RODRIGUES

https://orcid.org/0000-0003-3946-6441

\section{SILVANA C. THIENGO}

https://orcid.org/0000-0002-5547-206X

Instituto Oswaldo Cruz, Pavilhão Adolfo Lutz, Laboratório de Referência Nacional para Esquistossomose Malacologia, Fundação Oswaldo Cruz, Avenida Brasil, 4365, Manguinhos, 21040-360 Rio de Janeiro, RJ, Brazil

\section{Correspondence to: Suzete Rodrigues Gomes}

E-mail:suzetebio@yahoo.com.br

\section{Author contributions}

FCSR developed the project, carried out morphological and conquiological studies of the samples, and wrote the manuscript. SCT and SRG checked and supervised the identification of the specimens, the development of the project and the writing of the final manuscript. FCRS, SRG, SCT planned and participated in field expeditions to collect the samples. TC helped in the screening, preparing, and storing of the specimens and deposit in the Oswaldo Cruz Institute Mollusc Collection (CMIOC). PSR participated in the data tabulation to compose the map of the study area.

\section{(c) BY}

